\title{
ДО ПИТАННЯ ПРО КОНЦЕПЦІЮ ЛІНГВІСТИЧНОЇ БЕЗПЕКИ
}

Ситько О. М.

\begin{abstract}
Шляхом огляду наукової літератури й нормативних актів із питань безпеки визначено обсяг значення терміна "лінгвістична безпека» й сфери його застосування. Констатується, що лінгвістична безпека $\epsilon$ відносно новим поняттям, яке ще не отримало належного системного опису в науці. Найчастіше поняття лінгвістичної безпеки розглядається в контексті проблем національної безпеки, інформаційної безпеки, мовного суверенітету й мовної політики. Лінгвістична безпека уявляється як складова частина національної безпеки держави, хоча нормативно це не закріплено. Виділено три сторони поняття «лінгвістична безпека". По-перше, безпека самої мови, тобто ефективне й надійне функціонування мови й захист ії як від шкідливого впливу всередині неї самої, так і від зайвого, спричиненого білінгвізмом, проникнення до мови іншомовної лексики, граматики й фонетики.
\end{abstract} По-друге, лінгвістична безпека учасників будь-якої спільноти, об'єднаної комунікацією, від загроз, пов'язаних із належним функціонуванням мови й адекватним використанням їі можливостей. По-третє, безпека суспільних відносин, які регулюються державною мовною політикою, тобто питання впливу мови на ситуацію в державі й зовнішню політику, роль мови в підтриманні національної безпеки. Під лінгвістичною безпекою розуміється стан правової захищеності державної мови, за якого максимально повно забезпечується її безпечне існування, збереження цілісності, нормативності, функціональності, національнокультурної своєрідності, здатності до саморозвитку й самовдосконалення, а також система заходів щодо забезпечення саме такого розвитку мови. Це мовна політика, що виключає заподіяння шкоди системі мови під впливом внутрішніх і зовнішніх чинників, а також напрям наукових досліджень, який розглядає проблеми гарантування лінгвістичної безпеки. Особливим чином інтерпретується лінгвістична безпека тексту для учасників комунікації: сукупність принципів такого формування мовного тексту, за якого зводяться до мінімуму ризики його конфліктного сприйняття та відтворення.

Ключові слова: національна безпека, мовна політика, лінгвістична безпека, безпечна комунікація.

Sytko O. M. To the question on the concept of linguistic security

In the result of studies of various scientific resources and legal acts concerning the issues of security, the scope of the term "linguistic security" was determined, as well as an area of its application. It is stated that linguistic security is a relatively new concept that has not yet received a proper systemic description in science. Mostly, the concept of linguistic security is defined in the context of problems of national security, information security, linguistic sovereignty and language policy. Linguistic security is presented as an element of national security of the state, though without proper legal regulation. There are three aspects of the concept "linguistic security". First of all it refers to the security of the language, i.e. effective and safe functioning of the language and protection thereof from the negative influence from within the language itself, as well as from odd bilingualism caused by penetration into language of foreign vocabulary, grammar and phonetics. Secondly, this is linguistic security of any society members that are united by the communication, protected from the threats relating to the proper functioning of the language and adequate application of its possibilities. Third, the security of public relations, which are regulated by the state language policy, that is, the issue of language influence on the situation in the state and foreign policy; the role of language in maintaining national security. Under the linguistic security we understand the condition of legal protection of a language under which a fully secured existence thereof is guaranteed together with preserving of its integrity, normativity, functionality, national and cultural diversity, ability to self-development and self-improvement, as well as a system of measures for reaching this goal. This is a language policy that excludes harm to the language system under the influence of internal and external influences, as well as the direction of scientific research, considers the problems of ensuring linguistic security. The linguistic security of the text for the participants of communication is interpreted in a special way: a set of principles of text formation, which minimizes the risks of its inconsistent perception and reproduction.

Key words: national security, language policy, linguistic security, safe communication.

Постановка проблеми та іï актуальність. Агресія проти України, яка отримала назву гібридної війни, змінила наш погляд і ставлення до поняття безпеки та ії складників. У контексті

(c) Ситько О. М., 2020 
гібридної війни, за висновками фахівців, відбувається і війна різних цінностей і категорій буття, що покликана змінювати культурні, правові, політичні основи життєдіяльності суспільства й особистості, пропагуючи інший сенс буття, одночасно руйнуючи узвичаєне сприйняття світу [3]. Серед засобів для ураження та знищення інформаційної системи держави шляхом деструктивних впливів вчені виділяють і «лінгвістичну (протилінгвістичну) зброю», тобто засоби й способи дезінформації та дезорієнтації інформаційних діячів, ураження та знищення алгоритмів, неоднозначні мовні одиниці, суперечливі літеро-цифрові алфавіти й інше [6, с. 116]. Виходячи з наведеного, можна стверджувати, що чим вищий рівень розвитку інформаційної культури суспільства, яке протистоїть агресії, тим менше шансів у ворога перемогти в «гібридній війні». Тобто згадані події підкреслили важливість зміцнення серед інших і мовних основ безпеки [1].

Аналіз останніх досліджень і публікацій. Вітчизняні науковці, які працюють у різних галузях, неодноразово звертали увагу на такий важливий аспект гарантування національної безпеки, як підвищення статусу української мови як державної. Щоправда, іноді із цією метою використовуються не зовсім обґрунтовані аргументи: часто можна прочитати вислів “Cuius lingua, eius regio” («Чия мова, того й влада»), який приписують давньоримським мудрецям [17, с. 104], хоча насправді ця сентенція $є$ сучасним вільним тлумаченням принципу “Cuius regio, eius religio" («Чия влада, того й віра»), задекларованого під час укладення Аугсбурзького миру (1555 р.). Або під час аналізу мовного чинника національної безпеки України висловлюється думка про те, що «українська мова конкретно протистоїть російській» [4]. Неточність і нечіткість формулювань завжди змушують засумніватися в правильності обраного напряму дослідження, особливо якщо йдеться про гуманітарні знання.

Тема національної безпеки традиційно $є$ предметом жвавого обговорення серед вітчизняних дослідників, як правознавців, так і політологів. Проте вчені, підкреслюючи багатогранний характер безпеки та іï зв'язок з іншими науками, не згадують про мовознавство (лінгвістику). I хоча останнім часом методологічні підходи до визначення ключових понять і категорій основ національної безпеки відповідно до динамічних реалій багатовимірного соціально-політичного контексту змінюються [13], вони, схоже, не помічають, що підхід до всебічного аналізу безпеки пови- нен базуватися не лише на природних, соціальних і технічних знаннях, але також на відомостях лінгвістичних наук і теорії комунікації. Так, сформульовано поняття «політико-комунікативна безпека», яке визначено як атрибутивний елемент у системи національної безпеки, що забезпечує стабільність та ефективність політичних комунікацій, запобігає негативному чи деструктивному впливу на соціально-політичну систему в процесі здійснення внутрішніх і зовнішніх політичних комунікацій включно з євроінтеграційними [5]. Комунікативна безпека також розглядається як стан, за якого відбувається продуктивна внутрішня та зовнішня комунікація на засадах безпечності й дотримання етичних норм [9]. Нині фахівці цілком свідомо говорять про лінгвістичні війни, замкнуті на інформаційний простір у його цілісності, й новий різновид захисту національно-державної безпеки - лінгвістичну безпеку [12, с. 11]. Проте словосполучення «лінгвістична безпека» не стало нині в Україні широко використовуватися та не отримало системного аналізу [16].

Водночас у зарубіжних наукових публікаціях обґрунтовується комплексний підхід, за якого предметом дослідження крім безпечного й безперешкодного розвитку національної мови стають мова безпеки, безпека учасників мовної взаємодії та комунікативний аспект безпеки [7; 21]. Дедалі частіше говорять і пишуть про захист мовної ідентичності, мовної (та ширше - культурної) спадщини й насамперед національної ідентичності, але сам аспект лінгвістичної безпеки в широкому контексті національної безпеки ще не $\epsilon$ інтегрованим і мотивованим [19], а український законодавець, крім термінів, пов'язаних із культурною спадщиною та національною ідентичністю, вважає за краще використовувати поняття «захист державної мови».

Отже, незважаючи на достатню кількість зарубіжних наукових робіт у галузі факторів, критеріїв і порушень лінгвістичної безпеки, власне визначення такого поняття у вітчизняній теорії безпеки відсутнє, що деякою мірою розмиває горизонти подальших досліджень. Таким чином, перш ніж іти далі, слід спробувати визначити, що таке лінгвістична безпека?

Метою статті $\epsilon$ дослідження поняття «лінгвістична безпека» й сфери його застосування.

Виклад основного матеріалу. Окреслюючи зміст терміна «лінгвістична безпека», варто звернутися до суті розуміння самого поняття «безпека». Академічний тлумачний словник української мови дає таке визначення поняття 
«безпечний»: 1) який не має в собі небезпеки або захищає кого-, що-небудь від небезпеки; 2) якому не загрожує небезпека; гарантований від небезпеки; 3) який не завдає, не повинен завдавати шкоди [15, с. 139]. А поняття «безпека» подано більш лаконічно: «стан, коли кому-, чому-небудь ніщо не загрожує» [15, с. 137]. Отже, в такому випадку ми можемо розглядати безпеку як таку особливість чого-небудь, яка зводить до мінімуму шкоду й ризик її заподіяння в максимально допустимих нормах.

У ст. 1 Закону України «Про національну безпеку України» [8] національна безпека України визначається як «захищеність державного суверенітету, територіальної цілісності, демократичного конституційного ладу й інших національних інтересів України від реальних і потенційних загроз». За аналогічною схемою в законі окреслено поняття «воєнна безпека», «громадська безпека», «державна безпека». Слід зауважити, що концепція безпеки еволюціонує з розвитком цивілізації. Натепер безпека містить не тільки політичні й військові аспекти, але й економічні, екологічні, соціальні (й більш конкретні, наприклад туристичні [2, с. 20-23]). Тобто, узагальнивши наведені дефініції, поняття «безпека» можна визначити як стан захищеності певної системи від заподіяння шкоди, від певного виду загроз. В юридичній енциклопедії безпеку розрізняють за масштабом (міжнародну, регіональну, локальну); за суб'єктами (особисту, суспільну, національну, колективну); за суспільними сферами (політичну, економічну, військову, екологічну, радіаційну, громадську, інформаційно-комунікаційну) [18, c. 210-211].

Зважаючи на предмет нашого дослідження, слід докладніше розглянути комунікативну систему, зокрема лінійну модель комунікації для функціонального дослідження комунікативних подій, яку у XX ст. запропонував мовознавець Р. Якобсон. Його модель базується на відомій аристотелівській лінійній основі: адресант - повідомлення - адресат. Ця модель має форму трикутника, третьою його точкою $€$ контекст. Дослідник наголошує на тому, що повідомлення має співвідноситися з тим чи іншим контекстом. До трикутника додаються також контакт (фізичний канал i зв'язок між адресантом та адресатом) і код (загальна, однакова для адресанта й адресата система значень, які формують повідомлення) [20, с. 193-230]. Така модель набула значного поширення в лінгвістиці як для аналізу функцій мови в цілому, так і для аналізу окремих мовних одиниць. Отже, під комунікативною системою, яку необхідно захищати від заподіяння шкоди, тобто гарантувати іï безпеку, ми будемо мати на увазі комплексну ситуацію дискурсу, складовими частинами якої $\epsilon:$ 1) українська мова як система, 2) учасники комунікативного акту, 3) ситуація формування висловлювання (тексту).

1. Таким чином, уважаємо за необхідне й доцільне розглядати три сторони поняття «лінгвістична безпека»:

1. Забезпечення безпеки самої мови, тобто ефективного й надійного функціонування мови й захисту ії як від шкідливого впливу всередині неї самої, так і від зайвого, спричиненого білінгвізмом, проникнення до мови іншомовної лексики, граматики й фонетики.

2. Лінгвістична безпека учасників будь-якої спільноти, об'єднаної комунікацією, від загроз, пов'язаних із належним функціонуванням мови й адекватним використанням ії можливостей.

3. Безпека суспільних відносин, які регулюються державною мовною політикою, тобто питання впливу мови на ситуацію в державі й зовнішню політику, роль мови в підтриманні національної безпеки.

Отже, розглянемо ці три сторони поняття «лінгвістична безпека» докладніше.

1. Гарантування безпечного розвитку мови. На структуру мови безпосередньо впливає зовнішнє середовище, наприклад у разі появи нових слів або в разі зміни їхніх значень. Однак воно може впливати й опосередковано - через контактування мов, утворення літературної форми мови та іï вплив на народно-розмовну форму, розвиток жанрових різновидів мови, їі функціональних стилів і таке інше, тобто через усе те, що пов'язано 3 функціонуванням мови й виступає в ролі регулярного посередника між зовнішнім середовищем і структурою мови.

Зважаючи на неминучість і природність змін у мові, дослідникам доводиться констатувати розхитування норм сучасної української літературної мови. Нині лінгвісти зауважують загрозливе падіння рівня мовної культури в Україні, дотримання мовних норм української мови, динаміку моделей мовної поведінки й мовної картини світу. Зниження культури нашого мовлення, яке переповнене різного роду діалектизмами, плеоназмами, жаргонізмами, $\epsilon$ наслідком активного використання сленгів, жаргонів, суржику. На процес формування мовної особистості впливають як певні індивідуальні особливості мовця, так і зовнішні умови. Зокрема, потужним чинником, 
який визначає мовну особистість, $є$ білінгвізм. Це, звичайно, великою мірою впливає на культуру мовлення в суспільстві й призводить до деградації української мови. Це пов'язано насамперед із тими динамічними процесами, які стрімко змінюють мовні й комунікативно-прагматичні норми як в усній, так і в письмовій сферах комунікації.

Процес розхитування норм літературної мови може вважатися внутрішньою загрозою для мови, тобто порушенням їі цілісності й здатності до саморозвитку й саморегулювання. Водночас українська літературна мова перестає бути єдиним кодом, який має поєднувати носіїв мови, відповідно, перестає ефективно виконувати свою головну функцію - комунікативну. Для кращого виконання своїх важливих функцій у різних сферах людського життя літературна мова, особливо коли вона вживається в письмовій формі, повинна бути унормована в усіх своїх елементах - лексиці, фразеології, синтаксисі, морфології і так далі. Питання «правильності» мови десятиліттями не втрачають своєї актуальності, спонукаючи до періодичного оновлення, перегляду й доопрацювання правописного кодексу, граматики й словників. Пошук балансу між системними параметрами сучасної мови, з одного боку, й різночасовими прикметами української мовної традиції, з другого боку, - складне завдання, що ставиться перед творцями національного правопису. Важливим кроком до гарантування безпечного розвитку української мови з позицій її історичної та етнографічної соборності стала нова редакція правопису української мови, схвалена Кабінетом Міністрів України (Постанова № 437 від 22 травня 2019 р.) спільним рішенням Президії Національної академії наук України (протокол № 22/10 від 24 жовтня 2018 р.) і колегії Міністерства освіти і науки України (протокол № 10/4-13 від 24 жовтня 2018 р.) і затверджена Українською національною комісією з питань правопису (протокол № 5 від 22 жовтня 2018 р.).

2. 3 боку гарантування лінгвістичної безпеки учасників комунікативного акту в нашому дослідженні можна виділити аспекти, які можуть бути представлені на всіх рівнях: від міжособистісного до загальнонаціонального. Насамперед це захист об'єкта комунікації від загроз поширення та згубного впливу негативної інформації (особливо за умов так званої «інформаційної війни»). Наступним аспектом $\epsilon$ запобігання маніпулятивному впливу на реципієнта з метою спонукання до протиправних дій за допомогою текстів радикального характеру. Окрему увагу слід приділити мовній агресії (висловлювання, в яких міститься негативна інформація, спрямована на конкретного адресата для досягнення певного впливу, зокрема заподіяння образи, приниження особистої честі й гідності, їі ділової репутації, поширення свідомо хибних негативних відомостей та, як наслідок, зниження особистісного й соціального статусу адресата). Реалії комунікації сучасного світу виокремлюють такі сфери, де лінгвістичні вимоги, характеристики, ознаки $\epsilon$ настільки значущими, що можна говорити про сфери підвищеної мовленнєвої відповідальності. Такої відповідальності набувають комунікативні дії політика, журналіста, судді, поліцейського, оскільки висловлювання людей, які займаються подібною професійною діяльністю, відіграють важливу роль у житті суспільства в цілому й окремих громадян, визначаючи долю конкретної людини або ж впливаючи на громадську думку. Тому вивчення та дотримання лінгвістичних канонів і норм, а також особливостей функціонування мови у зв'язку із цим набуває важливого значення як для дослідження специфічних аспектів міжособистісної комунікації, так і з багатосторонньої мовної практики на державному й навіть міжнаціональному рівнях. На думку фахівців, нині ефективним інструментом ідентифікації гібридних загроз в інформаційному середовищі для учасників комунікації має стати лінгвістична експертиза. Настав час прикладного застосування лінгвістичного знання, зокрема методів міждисциплінарних наукових досліджень (нейролінгвістики, соціолінгвістики, психолінгвістики, етнолінгвістики й інших) [10]

3. Третій вектор розуміння поняття «лінгвістична безпека» полягає в гарантуванні безпечного розвитку суспільних відносин, які регулюються державною мовною політикою. Мова $\epsilon$ засобом ідеологічного впливу й вираження соціальної психології. Для забезпечення цілісності держави мова бере участь у формуванні національної та культурної ідентичності, а також у закріпленні форм суспільної свідомості, що дозволяє населенню країни усвідомлювати себе єдиним народом та ідентифікувати свою мовну поведінку з єдиним національним комунікативним простором. Проте нині національна мова в Україні не повною мірою $€$ тим соціокультурним механізмом, що забезпечує підтримання єдності українського народу в часі й просторі.

Серед проблем, які потребують розв'язання, фахівці виділяють:

збереження у свідомості значної частки населення України негативних стереотипів щодо 
статусу й місця української мови в суспільному, культурному житті;

- штучну заполітизованість та емоційну перевантаженість питання функціонування української мови в Україні, внаслідок чого мова використовується як інструмент політичної боротьби та $\epsilon$ предметом маніпуляцій;

ознаки дискримінації громадян на значній частині території України, де вони позбавлені або обмежені в отриманні послуг й контенту українською мовою;

- втрату мовної ідентичності населення та асиміляцію в російськомовному середовищі;

низький рівень володіння державною мовою серед представників національних меншин, що не дозволяє їм належно реалізовувати свої права й інтегруватися в українське суспільство;

- недостатній рівень задоволення національно-культурних і мовних потреб українців, які проживають за кордоном;

- відсутність у частини українського суспільства самоідентифікації з Україною; відсутність цілісного українського мовно-культурного простору, що пов'язано, зокрема, з неналежним інституційним, фінансовим і кадровим забезпеченням реалізації державної мовної політики.

Таким чином, мова «потребує захисту», який покликана забезпечити діяльність держави й інших політичних сил щодо встановлення статусу мови в суспільстві, тобто мовна політика. Проте «успіх відродження національних мов і культур, що переживають тривалий період пригнічення, залежить від поєднання двох чинників: колективної волі до незалежності й свідомих зусиль національної еліти, яка впроваджує в державі мовну політику протекціонізму своєї культури» [11, с. 95].

Держава повинна сприяти всебічному розвитку української мови як основного інструменту перетворення нагромаджених людством знань в інформаційний ресурс України [14]. Йдеться про усвідомлений вплив держави на функціонування, розвиток мови та її основних функцій. Тому українським законодавцем в останні роки було ухвалено декілька стратегічних документів у такому напрямі:

Стратегія сталого розвитку «Україна - 2020», схвалена указом Президента України від 12 січня 2015 р. № 5 (зокрема, охоплює всі визначені вектори руху України: сталий розвиток країни; безпеку держави, бізнесу й громадян; відповідальність і соціальну справедливість; гордість за Україну в Європі й світі, оскільки досягнення цих цілей неможливе без розвитку й популяризації української мови);
Програма діяльності Кабінету Міністрів України, затверджена постановою Кабінету Міністрів України від 14 квітня 2016 р. № 294 та схвалена постановою Верховної Ради України від 14 квітня 2016 р. № 1099-VIII, щодо розвитку української мови;

- середньостроковий план пріоритетних дій Уряду до 2020 р., затверджений розпорядженням Кабінету Міністрів України від 3 квітня 2017 р. № 275, одним із пріоритетів якого $\epsilon$ зміцнення позицій державної мови в культурно-інформаційному просторі;

- Закон України «Про забезпечення функціонування української мови як державної», ухвалений Верховною Радою України 25 квітня 2019 р. та 15 травня підписаний Президентом України.

Окремої уваги заслуговує Стратегія популяризації української мови до 2030 р. «Сильна мова - успішна держава», схвалена розпорядженням Кабінету Міністрів України від 17 липня 2019 р. № 596-р. ІІї метою $є$ утвердження української мови на всій території України в усіх сферах суспільного життя, яке забезпечує єднання українського суспільства й зміцнення його української ідентичності. Необхідність прийняття стратегії обґрунтовується тим, що всебічний розвиток української мови як однієї з найважливіших складових частин національної ідентичності українського народу є гарантією національної безпеки.

Отже, для забезпечення лінгвістичної безпеки українського суспільства необхідно виявляти й оцінювати деструктивні впливи, яких зазнає система української мови, вивчати потреби, інтереси, мотиви й стимули носіїв мови для запобігання втрати ними того лінгвістичного коду, який дає змогу зберігати унікальну мовну картину світу, наглядати за дотриманням правил мовленнєвої діяльності, формуванням мовної особистості й збереженням української мови як частини національної культури, прогнозувати дії суб'єктів, які беруть участь у забезпеченні цього виду безпеки, просувають і реалізують інтереси держави в мовній сфері.

Висновки. Лінгвістична безпека є відносно новим поняттям, яке ще не отримало належного системного опису в науці, що цілком пояснюється його науковою новизною та багатоаспектністю. Найчастіше поняття лінгвістичної безпеки обумовлюється в контексті проблем національної безпеки, інформаційної безпеки, мовного суверенітету й мовної політики. Лінгвістичну безпеку ми уявляємо як складову частину національної безпеки держави, проте нині нормативно це не закріплено.

Під лінгвістичною безпекою ми розуміємо стан правової захищеності державної мови, за якого 
максимально повно забезпечується іï безпечне існування, збереження цілісності, нормативності, функціональності, національно-культурної своєрідності, здатності до саморозвитку й самовдосконалення, а також система заходів щодо забезпечення саме такого розвитку мови. Це мовна політика, що виключає заподіяння шкоди системі мови під впливом внутрішніх і зовнішніх впливів, а також напрям наукових досліджень, що розглядають проблеми забезпечення лінгвістичної безпеки. Особливим чином можна інтерпретувати лінгвістичну безпеку тексту для учасників комунікації: це сукупність принципів такого формування мовного тексту, за якого зводяться до мінімуму ризики його конфліктного сприйняття та відтворення.

\section{Література}

1. Актуальні проблеми управління інформаційною безпекою держави : зб. тез наук. доп. наук. практ. конф., М. Київ, 4 квітня 2019 р. Київ : Нац. акад. СБУ, 2019. 384 с.

2. Голод А.П. Туристичне безпекознавство як перспективний напрям наукових досліджень. Сучасний стан, проблеми та перспективи розвитку туризму в регіонах України : мат. II Всеукр. наук.практ. конф., М. Львів, 18-19 травня 2017 р. Львів, 2017. C. 20-23.

3. Горбулін В.П. Світова гібридна війна: український фронт. Київ : Нац. ін-т стратегічних досліджень, 2017. 496 с.

4. Демченко В.М. Державна мова як об'єкт національної безпеки : монографія / за наук. ред. проф. І.П. Лопушинського. Херсон : Вид-во ПП Вишемирський В.С., 2019. 176 с.

5. Дубов Д.В. Політико-комунікативна безпека України у євроінтеграційному контексті : дис. ... канд. політ. наук : 21.01.01 ; Національний ін-т проблем міжнародної безпеки Ради національної безпеки та оборони України. Київ, 2007. 218 с. Бібліогр.: С. 197-216.

6. Інформаційна безпека особистості, суспільства, держави : Підручник / Я.М. Жарков, М.Т. Дзюба, І.В. Замаруєва та ін. Київ : Видавничо-поліграфічний центр «Київський університет», 2008. 274 с.

7. Жигалев Б.А., Устинкин С.В. Лингвистическая безопасность как фактор обеспечения устойчивого развития Российской Федерации. Власть. 2015. № 10. С. 32-41.

8. Про національну безпеку України : Закон України від 21 червня 2018 року № 2469-VIII / Верховна Рада України. Відомості Верховної Ради Українu. 2018. № 31. Ст. 241.

9. Коленда Н.В. Мотиваційна безпека: теоретичний аспект. Інфраструктура ринку. 2019. Вип. 37. С. 265-269.
10. Компанцева Л.Ф. Лінгвістична експертиза соціальних мереж в умовах гібридних викликів національній безпеці України. Актуальні проблеми української лінгвістики: теорія і практика. 2020. № 40. С. 119-139.

11. Масенко Л.Т. Мова і політика. Київ, 1999. $100 \mathrm{c}$.

12. Парадигмально-категорійні основи прикладної лінгвістики : монографія / А.П. Загнітко, І.Г. Данилюк, Ж.В. Краснобаєва-Чорна та ін. Вінниця : «ТОВ Нілан-ЛТД», 2015. 472 с.

13. Полтораков О.Ю. Реконцептуалізація поняття «безпека» в сучасному політико-політологічному дискурсі. Політичний менеджмент. 2009. № 5. С. 19-28.

14. Роговець В.О. Інформаційні війни в сучасному світі: причини, механізми, наслідки. Персонал. 2000. № 5. С. 33-38.

15. Безпечний. Словник української мови : в 11 томах. T. 1. 1970. C. 139. URL: http:// sum.in.ua/p/1/139/1.

16. Тарасюк Ю.М. Поняття про лінгвістичну безпеку та мовну політику Туреччини в контексті процесу модернізації. Вісник Одеського національного університету ім. І. Мечникова. Сочіологічні і політичні науки. 2016. Т. 21. Вип. 4 (27). C. 70-76.

17. Чеховська М.М., Шлапаченко В.М. Державна мова як складова інформаційного суверенітету держави. Інформаційна безпека людини, суспільства, держави. 2018. № 2 (24). С. 104-116.

18. Юридична енциклопедія : словник-довідник : В 6 т. / укл.: Ю.С. Шемшученко, М.П. Зюблюк, В.П. Горбатенко та ін. / НАНУ. Ін-т держави і права ім. В.М. Корецького ; Гол. ред. Ю.С. Шемшученко. Т. 5: П-С. Київ : Українська енциклопедія ім. М.П. Бажана, 2003. 736 с.

19. Юрислінгвістика : словник термінів і понять / уклад. : Л.І. Шевченко, Д.В. Дергач, Д.Ю. Сизонов, І.В. Шматко ; За ред. докт. філол. н., проф. Л.І. Шевченко. Київ : ВПЦ «Київський університет», 2015. $334 \mathrm{c}$.

20. Якобсон Р. Лингвистика и поэтика. Структурализм: «за» и «против». Москва, 1975. C. $193-230$.

21. Stawnicka J. Dyskurs o bezpieczeństwie z perspektywy lingwosecuritologii. Katowice : Wydawnictwo Uniwersytetu Śląskiego, 2016. 134 s.

Ситько О. М., кандидат філологічних наук, доцент, завідувач кафедри іноземних мов Одеського державного університету внутрішніх справ 